\title{
Chemical Ecology of Astigmatid Mites LXXIII. Neral as an Alarm Pheromone of the Acarid Mite, Oulenzia sp. (Astigmata: Winterschmidtiidae)
}

\author{
Nobuhiro ShIMIZU, Koji Noge, Naoki Mori, Ritsuo NishIDA \\ and Yasumasa KUWAHARA* \\ Laboratory of Chemical Ecology, Division of Applied Life Science, Graduate School of Agriculture, \\ Kyoto University, Sakyo-ku, Kyoto 606-8502, Japan
}

(Received 23 June 2003; Accepted 10 March 2004)

\begin{abstract}
Hexane extracts derived from an unidentified Oulenzia sp. showed the alarm pheromone activity. The extract was composed of the following 10 compounds; tridecane, neral, pentadecane, dodecane, 3hydroxybenzene-1,2-dicarbaldehyde, geranial, (Z)-7-pentadecene and 7-hydroxyphthalide in decreasing order together with two unknown compounds. After fractionation with a silica gel column, the active fraction consisted of a mixture of neral and geranial. Neral was found to show the activity, but geranial was not. Neral was, therefore, identified as the alarm pheromone of this species.
\end{abstract}

Key words: Astigmatid mite, Winterschmidtiidae, alarm pheromone, Oulenzia sp., neral

\section{INTRODUCTION}

Alarm pheromones are known in 16 species belonging to six families from 52 species in nine families of Astigmata investigated. Active components of these pheromones are secreted from a pair of opisthonotal glands present in each species (Kuwahara et al., 1979 and 1980; Mizoguchi et al., 2003). Chemical structures of the pheromones so far known are classified into three groups; 1) monoterpenes, 2) aromatics and 3) hydrocarbons (Kuwahara, 1999). The monoterpenes consist of five compounds; neryl formate in six species [four species belong to the genus Rhizoglyphus (Akiyama et al., 1997), Tyroborus lini (Tomita et al., 2003), and Tyrophagus putrescentiae (Kuwahara et al., 1975)], neral in five species [Carpoglyphus lactis (Kuwahara and Suzuki, 1983), Glycyphagus domesticus (Kuwahara et al., 1991a), Suidasia medanensis (Leal et al., 1989), Lardoglyphus konoi (Kuwahara et al., 1980) and Schwiebaea elongata (Kuwahara et al., 2001)], geranial in Histiostoma laboratorium (Kuwahara et al., 1991b), isopiperitenone in Tyrophagus similis (Kuwahara et al., 1987) and $\beta$-acaridial in Tyrophagus longior (Noguchi et al., 1998). The aromatic compound 2-hydroxy-6-methylbenzaldehyde functions as the pheromone in Tyrophagus perniciosus (Leal et al., 1988). A mixture of alkenes $\left(\mathrm{C}_{13}-\mathrm{C}_{15}\right)$ in Tyrophagus neiswanderi (Kuwahara et al., 1989) and (Z,Z)-6,9-heptadecadiene in Tortonia sp. (Kuwahara et al., 1995), are also known as the alarm pheromones. No relationships have been recognized between the

*Corresponding author: e-mail: kuwa34@kais.kyoto-u.ac.jp; fax: +81-75-753-6312 
chemical structures of alarm pheromones and taxonomic status of Astigmata.

Other than alarm pheromones, sex and aggregation pheromones are also present as the same gland components of Astigmata (Kuwahara et al., 1980; Mizoguchi et al., 2003), and it is reasonable to understand that each species can handle a kind of pheromone function within the three. Recently, it has been realized that a species of mites can manipulate at least two kinds of pheromones (Kuwahara, 2001), such as found in Rhizoglyphus robini where a combination of the alarm and sex pheromones (neryl formate and $\alpha$-acaridial, respectively) present in the same gland is manipulated to show each own function (Mizoguchi et al., 2003), and as found in Schwiebea elongata where neral functions not only as an alarm pheromone at a high dose but also as an attractant at a low dose, possibly an aggregation pheromone (Nishimura et al., 2002). Therefore, a new identification of the alarm pheromone from an unidentified mite Oulenzia sp. (Astigmata: Winterschmidtiidae) may serve as a basic knowledge for further understanding of mite's multiple pheromone systems.

Oulenzia sp. is collected twice from banana and rambutan in the Philippines. Based on behavioral observations (Kuwahara et al., 1975), the presence of an alarm pheromone is also conceivable. A bioassay method (Tomita et al., 2003) originally devised for the present species was successfully applied for the study. We report here the identification of neral as the alarm pheromone of Oulenzia sp. triggering mite repellent behavior. This pheromone is distributed in both sexes and its content can be quantitatively determined. We evaluated the alarm pheromone activity using purified neral fraction and synthetic neral with a simple bioassay method.

\section{MATERIALS AND METHODS}

Mites. An unidentified species of the genus Oulenzia (Astigmata: Winterschmidtiidae) whose ITS2 region consisted of 289 or 282 bps (code name OL 50, GenBank Accession Number: AB104992 and AB104993) was a population collected in June 1997 from the deteriorated parts of organic banana produced in the Philippines. Males exhibit guarding behavior for tritonymphs at resting period. A pair of opisthonotal glands is visible under binocular microscope in the opisthosoma as brown spots. The strain was fed on dry yeast at room temperature under $70 \%$ relative humidity in a plastic culture dish $(85 \mathrm{~mm}$ in diameter, $20 \mathrm{~mm}$ depth) with the bottom surface covered with a sheet of filter paper. Each dish was kept in a zip-lock polyethylene bag $(240 \times 170 \mathrm{~mm}, 0.04 \mathrm{~mm}$ film thickness, Seisan-nihon Co. Ltd.) twice to maintain the humidity. When the mite number reaches a certain level in a stock culture, this species starts to escape naturally from the medium and to stay on the inner surface of the dish. Such a cover dish with an appropriate mite number was used for behavioral experiments.

Analytical methods. Gas liquid chromatography (GC) was conducted with a Hewlett Packard 5890 series II Plus equipped with FID and an HP-5 capillary column $(0.25 \mathrm{~mm}$ in diameter $\times 30 \mathrm{~m}, 0.25 \mu \mathrm{m}$ film thickness, Hewlett Packard, split-less mode) at a temperature programmed from $60^{\circ} \mathrm{C}$ (with an initial 2-min hold) to $290^{\circ} \mathrm{C}$ (with a 5 -min hold) at $10^{\circ} \mathrm{C} /$ min. Gas liquid chromatography coupled with mass spectrometry (GC/MS) was carried out with a Hewlett Packard HP-5989B gas chromatograph-mass spectrometer operated at $70 \mathrm{eV}$ 
in the splitless mode and an HP-5 MS capillary column $(0.25 \mathrm{~mm} \times 30 \mathrm{~mm}, 0.25 \mu \mathrm{m}$ film thickness) under the same conditions as described above.

Bioassay method. The activity was evaluated as reported (Tomita et al., 2003) with minor modifications. A cover dish with an appropriate mite number as described above was placed upside down on a sheet of paper, on which many circles (6 $\mathrm{mm}$ in diameter) were previously printed. Selecting arbitrarily a resting mite (without differentiating sexes, and conditioning), the paper underneath was gently shifted to set the mite in the center of circle. A piece of filter paper $(2 \times 1 \mathrm{~mm})$ impregnated with a candidate sample, such as $1 \mu \mathrm{l}$ (about 3 female equivalent) of the whole-mite extract $(1 \mathrm{ml})$ or $10 \mu \mathrm{l}$ of its each separated fraction $(10 \mathrm{ml})$, was placed within the circle with the least physical disturbance. The time (in seconds) required for the mite to be aroused and to leave the test circle was measured under a binocular microscope for 120 seconds after exposure to the alarm pheromone. Hexane was used as a control. This assay was repeated 10 times at room temperature under ambient humidity. Resulting data were processed to evaluate significant differences in the required time by a Mann-Whitney $U$ test or a Kruskal-Wallis test followed by Dunn's multiplecomparison test.

Extraction and purification of the pheromone. Ten males or females were transferred to a conical-bottomed tube (handmade, $8 \mathrm{~mm}$ in outer diameter $\times 30 \mathrm{~mm}$ in height) from the stock culture, and extracted with $4 \mu \mathrm{l}$ of hexane for $3 \mathrm{~min}$. The hexane extract was collected with a microsyringe, and subjected to GC/MS analysis without concentration to monitor compositions. To determine the active compound(s), mites $(110 \mathrm{mg})$ including all developmental stages were separated from the culture medium by the conventional saline flotation method (Matsumoto, 1965), and dipped in hexane $(1 \mathrm{ml})$ for $3 \mathrm{~min}$. The resulting hexane extract, after evaporating the solvent, was applied to a silica gel column (1.0 g, Wako-gel C-200), and eluted with $10 \mathrm{ml}$ each of the following solvents: hexane, hexane-ether (20:1), (10:1) and $(5: 1)$, and ether. The activity and composition of each eluate were monitored by bioassay, GC and GC/MS.

Quantitative determination of the pheromone. A male or a female was placed with a needle into a conical-bottomed tube. Hexane $(3 \mu \mathrm{l})$ containing hexadecane $(60 \mathrm{ng})$ as an internal standard was added to each tube for extraction. After $3 \mathrm{~min}, 1 \mu \mathrm{l}$ of the extract corresponding to $1 / 3$ male or female equivalent was subjected to GC analysis. The quantity of neral per male or female was determined by the relative ratio of the peak area to that of the internal standard from 10 replicates.

Preparation of neral and geranial. Neral (content of geranial less than 1\%) and geranial (content of neral less than $1 \%$ ) were each synthesized by the active $\mathrm{MnO}_{2}$ oxidation of nerol and geraniol, respectively (Leal et al., 1989).

\section{RESULTS}

\section{GC/MS analysis of the hexane extracts}

The hexane extracts were composed of the following 10 compounds in decreasing order: tridecane, neral [(Z)-3,7-dimethyl-2,6-octadienal], pentadecane, dodecane, unknown peak $\left(238 / 69, t_{\mathrm{R}}: 13.43 \mathrm{~min}\right), 3$-hydroxybenzene-1,2-dicarbaldehyde ( $\gamma$-acaridial, Sakata and 
Kuwahara, 2001), geranial [(E)-3,7-dimethyl-2,6-octadienal], (Z)-7-pentadecene, unknown peak $\left(136 / 69, t_{\mathrm{R}}: 9.31 \mathrm{~min}\right)$, 7-hydroxyphthalide (7-hydroxy-3H-isobenzofuran-1-one, Shimizu and Kuwahara, 2001), including two unknown peaks $\left(\mathrm{M}^{+}\right.$ion/the base ion peak). The eight compounds identified are summarized in Table 1. No peculiar differences were observed in the chromatographic profiles of males and females.

\section{Identification of the alarm pheromone}

When a filter paper impregnated with the hexane extract $(1 \mu \mathrm{l})$ was introduced in the vicinity of a resting adult mite in the center of a circle, the mite began moving and left the circle. The time $(9.4 \pm 1.5 \mathrm{sec}$.) for a mite to leave of the test circle was significantly different from the control (36.6 $\pm 6.5 \mathrm{sec}$.) (Mann-Whitney $U$ test, $p<0.05)$ (Fig. 1). We concluded an alarm pheromone was present in this species.

After fractionaton of the mite extract with a silica gel column chromatography, the pheromone activity was recovered in a fraction eluted with a hexane-ether (10:1) mixture (Fig. 2). All the other fractions were entirely inactive. Significant differences were demonstrated

Table 1. GC/MS data for compounds obtained from the hexane extract of Oulenzia sp.

\begin{tabular}{|c|c|c|}
\hline Compound & $\underset{\mathrm{t}_{R}(\mathrm{~min})}{\mathrm{GC}}$ & $\begin{array}{l}\text { Diagnostic ions } \\
m / z \text { (intensity } \%)\end{array}$ \\
\hline Dodecane & 8.85 & $\begin{array}{l}43(72), 57(100), 71(64), 85(41), 99(12) \\
113(10), 127(9), 141(5), 170\left(\mathrm{M}^{+}, 26\right)\end{array}$ \\
\hline Neral & 9.53 & $\begin{array}{l}41(90), 69(100), 84(34), 94(46), 109(32) \\
119(20), 134(12), 137(8), 152\left(\mathrm{M}^{+}, 3\right)\end{array}$ \\
\hline Geranial & 9.90 & $\begin{array}{l}41(69), 69(100), 84(30), 94(22), 109(10) \text {, } \\
123(9), 137(13), 152\left(\mathrm{M}^{+}, 9\right)\end{array}$ \\
\hline $\begin{array}{l}\text { 3-Hydroxybenzene- } \\
\text { 1,2-dicarbaldehyde }\end{array}$ & 10.20 & $\begin{array}{l}51(5), 63(9), 65(22), 76(7), 93(33), \\
121(100), 122(55), 149(9), 150\left(\mathrm{M}^{+}, 93\right)\end{array}$ \\
\hline Tridecane & 10.30 & $\begin{array}{l}43(66), 57(100), 71(73), 85(49), 99(14) \\
113(9), 127(9), 141(7), 184\left(\mathrm{M}^{+}, 24\right)\end{array}$ \\
\hline 7-Hydroxyphthalide & 11.40 & $\begin{array}{l}51(5), 65(14), 77(2), 93(15), 105(2), \\
121(100), 122(9), 149(12), 150\left(\mathrm{M}^{+}, 71\right)\end{array}$ \\
\hline Z-7-Pentadecene & 12.78 & $\begin{array}{l}41(69), 55(100), 69(90), 83(91), 97(76) \\
111(43), 125(17), 137(9), 210\left(\mathrm{M}^{+}, 48\right)\end{array}$ \\
\hline Pentadecane & 12.85 & $\begin{array}{l}41(30), 43(68), 57(100), 71(72), 85(44) \\
99(16), 113(9), 127(6), 212\left(\mathrm{M}^{+}, 11\right)\end{array}$ \\
\hline
\end{tabular}

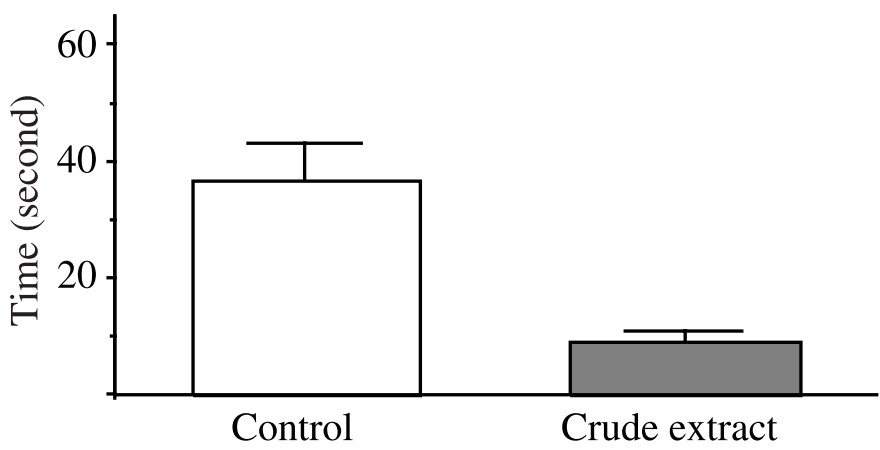

Fig. 1. Alarm pheromone activity of the hexane extract from Oulenzia sp. Significant difference $(p<0.05$, each $n=10)$. 


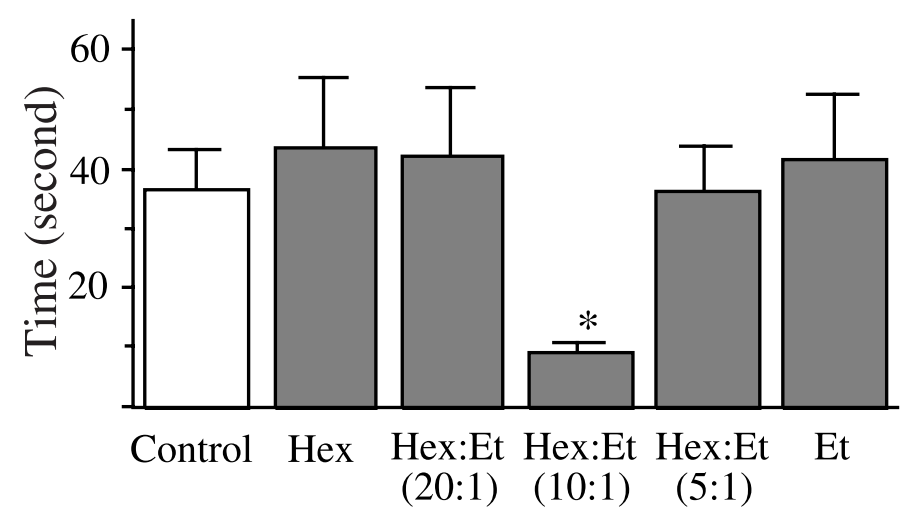

Fig. 2. Alarm pheromone activity of each silica gel column fraction (Hex: hexane; Et: diethyl ether). Significant difference $(* p<0.05$, each $n=10)$.

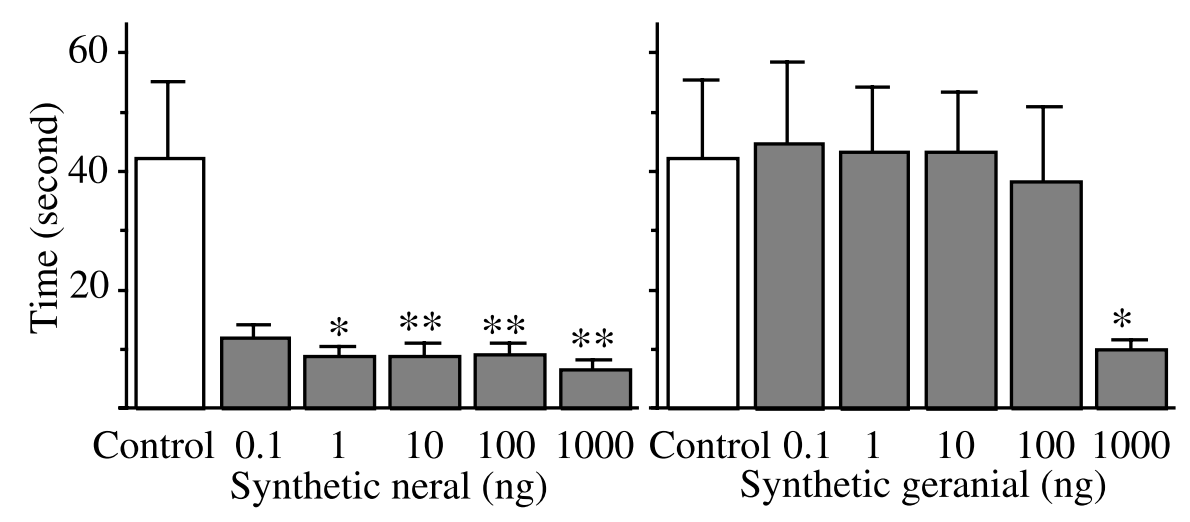

Fig. 3. Alarm pheromone activity of synthetic neral and geranial. Significant difference $(* p<0.05$, ** $p<0.01$, each $n=10)$.

between the active fraction and the control (Kruskal-Wallis test followed by the Dunn's multiple-comparison test, $p<0.01)$. The active fraction monitored by GC/MS analyses consisted of two peaks ( 9.53 and $9.90 \mathrm{~min}$ ) identified as neral (relative abundance; $95 \%$ ) and geranial (relative abundance; $5 \%$ ). Therefore, neral and (or) geranial are suggested as alarm pheromones.

\section{Evaluation of the synthetic alarm pheromone}

Synthetic neral showed the alarm pheromone activity at doses of 1-1000 ng, which were statistically significant at $p<0.01$ or $p<0.05$ (Kruskal-Wallis test followed by the Dunn's multiple-comparison test) (Fig. 3). There was no significant difference between a $0.1 \mathrm{ng}$ dose of neral and the control. On the other hand, synthetic geranial indicated no alarm pheromone activity at dosed of 0.1-100 ng, while geranial at a dose of $1000 \mathrm{ng}$ was active (Fig. 3). As a result, neral was concluded as the alarm pheromone of this species. The quantity of neral determined by GC in the hexane extract was $1.05 \pm 0.20 \mathrm{ng}$ per male and $0.75 \pm 0.13 \mathrm{ng}$ per female (each an average of 10 replicates), respectively. 


\section{DISCUSSION}

The alarm pheromone of this Oulenzia sp. was identified as neral active at $1-1000 \mathrm{ng}$ (significant at $p<0.05$ for $1 \mathrm{ng}$ and at $p<0.01$ at 10,100 and $1000 \mathrm{ng}$ ). The dose-response relationship seemed to be sigmoidal, similar to other alarm pheromones (Nishimura et al., 2002). On the other hand, geranial (isomeric purity $>99 \%$ ), the geometric isomer of neral, was only active at $1000 \mathrm{ng}$ (significant at $p<0.05$ ). This activity, however, can be explained by the presence of neral at a dose of $10 \mathrm{ng}$. Based on these results, we concluded that neral was the alarm pheromone of this species and geranial was inactive.

Neral is one of the most widely distributed monoterpene pheromone among astigmatid mites (in six species including the present study), together with neryl formates (distributed in six species) (Kuwahara, 1999, 2001). On the other hand, geranial has been shown as the alarm pheromone only in one species of Astigmata H. laboratorium (Kuwahara et al., 1991b) among 52 species examined.

The amount of neral in the mite $(1.05 \pm 0.20 \mathrm{ng}$ for a male and $0.75 \pm 0.13 \mathrm{ng}$ for a female) is almost consistent with that to stimulate the alarm pheromone activity. This fact indicates that total discharge from either sex is necessary to release the alarm pheromone behavior among test mites. The same situation, total discharge of an active component required, has been evidenced in at least two other cases of $R$. robini (Mizoguchi et al., 2003) and T. lini (Tomita et al., 2003), and seems to be a common phenomenon in alarm pheromones. For better understanding of mite's multiple pheromone systems, further evidence must be accumulated to investigate the condition, in which alarm pheromones function in Astigmata.

In addition, the first example of the alarm pheromone in Oribatida has been reported from nymphs of Nothrus palustris (Shimano et al., 2002). Its active principle is geranial, and its presence is limited only in nymphal stages. Because oribatid species belonging to four cohorts among six cohorts are known to possess the same opisthonotal gland as Astigmata, and volatiles possibly functioning as defense compounds (Shimano, 2001) have been identified among 60 species examined (Raspotnig et al., 2002; Sakata and Norton, 2001; Sakata et al., 2003; Shimano et al., 2002), it is of no wander to find further examples of alarm pheromones among Oribatida, like cases of Astigmata.

\section{ACKNOWLEDGMENTS}

The authors thank Dr. Kimiko Okabe, Forestry and Forest Products Research Institute, Tsukuba, Japan, for identifying mite species. This study was partly supported by a grant-aid for scientific research from Ministry of Education, Science, Sports and Culture of Japan (nos. 08406010, 09556010, 09876091 and 8956). Nobuhiro shimizu is the recipient of a research fellowship (no. 01761) from the Japan Society for the Promotion of Science for Young Scientists.

\section{REFERENCES}

Akiyama, M., T. Sakata, N. Mori, T. Kato, H. Amano and Y. Kuwahara (1997) Chemical ecology on astigmatid mites. XLVI. Neryl formate, the alarm pheromone of Rhizoglyphus setosus Manson (Acarina: Acaridae) and the 
common pheromone component among four Rhizoglyphus mites. Applied Entomology and Zoology, 32: 75-79.

Kuwahara, Y., S. Ishii and H. Fukami (1975) Neryl formate: Alarm pheromone of the cheese mite, Tyrophagus putrescentiae (Schrank) (Acarina, Acaridae). Experientia, 31: 1115-1116.

Kuwahara, Y., H. Fukami, S. Ishii, K. Matsumoto and Y. Wada (1979) Pheromone study on acarid mites II. Presence of the alarm pheromone in the mold mite, Tyrophagus putrescentiae (Schrank) (Acarina, Acaridae) and the site of its production. Japanese Journal of Sanitary Zoology, 30: 309-314.

Kuwahara, Y., K. Matsumoto and Y. Wada (1980) Pheromone study on acarid mite IV. Citral: composition and function as an alarm pheromone and its secretory gland in four species of acarid mites. Japanese Journal of Sanitary Zoology, 31: 73-80.

Kuwahara, Y. and H. Suzuki (1983) Pheromone study on acarid mites XI. Function of mite body as geometrical isomerization and reduction of citral (the alarm pheromone). Applied Entomology and Zoology, 18: 30-39.

Kuwahara, Y., K. Akimoto, W. S. Leal, H. Nakao and T. Suzuki (1987) Isopiperitenone: a new alarm pheromone of the acarid mite, Tyrophagus similis (Acarina, Acaridae). Agricultural and Biological Chemistry, 51: 3441-3442.

Kuwahara, Y., W. S. Leal, Y. Nakano, Y. Kaneko, H. Nakao and T. Suzuki (1989) Pheromone study on astigmatid mites XXIII. Identification of the alarm pheromone on the acarid mite, Tyrophagus neiswanderi and species specificities of alarm pheromones among four species of the same genus. Applied Entomology and Zoology, 24: 424-429.

Kuwahara, Y., T. Koshii, M. Okamoto, K. Matsumoto and T. Suzuki (1991a) Chemical ecology on astigmatid mites XXX. Neral as the alarm pheromone of Glycyphagus domesticus (De Geer) (Acarina, Glyciphagidae). Japanese Journal of Sanitary Zoology, 42: 29-32.

Kuwahara, Y., T. Sato and T. Suzuki (1991b) Chemical ecology on astigmatid mites XXXI. Geranial as the alarm pheromone of Histiostoma laboratorium Hughes (Astigmata; Histiostomidae). Applied Entomology and Zoology, 26: 501-504.

Kuwahara, Y., M. Ohshima, M. Sato, K. Kurosa, S. Matsuyama and T. Suzuki (1995) Chemical ecology of astigmatid mites XL. Identification of the alarm pheromone and new $\mathrm{C} 17$ hydrocarbons from a Tortonia sp., a pest attacking the nest of Osmia cornifrones. Applied Entomology and Zoology, 30: 177-184.

Kuwahara, Y. (1999) Chemical ecology of astigmatid mites. In: Environmental Entomology (eds., T. Hidaka, Y. Matsumoto, K. Honda, H. Honda and S. Tatsuki). University of Tokyo Press, Tokyo, pp. 380-393. (In Japanese)

Kuwahara, Y. (2001) Semiochemicals in Astigmatid mites. In: Biology of Ticks and Mites (ed., J. Aoki). University of Tokyo Press, Tokyo, pp. 111-129. (In Japanese)

Kuwahara, Y., T. Ibi, Y. Nakatani, A. Ryono, N. Mori, T. Sakata, K. Okabe, K. Tagami and K. Kurosa (2001) Chemical ecology of astigmatid mites LXI. Neral, the alarm pheromone of Schwiebea elongata (Acari: Acaridae). Journal of the Acarological Society of Japan, 10: 19-25.

Leal, W. S., Y. Nakano, Y. Kuwahara, H. Nakao and T. Suzuki (1988) Pheromone study on acarid mites XVII. Identification of 2-hydroxy-6-methyl-benzaldehyde as the alarm pheromone of the acarid mite, Tyrophagus perniciosus (Acarina: Acaridae), and its distribution among related mites. Applied Entomology and Zoology, 23: $422-427$.

Leal, W. S., Y. Kuwahara, T. Suzuki and K. Kurosa (1989) The alarm pheromone of the mite Suidasia medanensis Oudemans, 1924 (Acariformes, Suidasiidae). Agricultural and Biological Chemistry, 53: 2703-2709.

Matsumoto, K. (1965) Studies on the environmental factors for the breeding of grain mites VI. Digestive enzymes of the grain mites Carpoglyphus lactis, Aleuroglyphus ovatus and Tyrophagus dimidiatus. Japanese Journal of Sanitary Zoology, 16: 86-89.

Mizoguchi A., N. Mori, R. Nishida and Y. Kuwahara (2003) $\alpha$-Acaridial as the female sex pheromone from an alarm pheromone emitting mite Rhizoglyphus robini. Journal of Chemical Ecology, 29: 1681-1690.

Nishimura, K., N. Shimizu, N. Mori and Y. Kuwahara (2002) Chemical ecology of astigmatid mites. LXIV The alarm pheromone neral functions as an attractant in Schwiebea elongata (Banks) (Acari: Acaridae). Applied Entomology and Zoology, 37: 13-18.

Noguchi, S., N. Mori, K. Kurosa and Y. Kuwahara (1998) Chemical ecology of astigmatid mites XLIX. $\beta$-Acaridial [2(E)-(4-methyl-3-pentenylidene)-butanedial], the alarm pheromone of Tyrophagus longior Gervais (Acarina; Acaridae). Applied Entomology and Zoology, 33: 53-57.

Raspotnig G., R. Schuster, G. Krisper, G. Fauler and H. J. Leis (2002) Chemistry of the oil gland secretion of Collo- 
hmannia gigantea Sellnick, 1992 (Acari: Oribatida). Experimental and Applied Acarology, 25: 933-946.

Sakata, T. and Y. Kuwahara (2001) Structural Elucidation and Synthesis of 3-Hydroxybenzene-1,2-dicarbaldehyde from Astigmatid Mites. Bioscience, Biotechnology, and Biochemistry, 65: 2315-2317.

Sakata, T. and R. A. Norton (2001) Opisthonotal gland chemistry of early-derivative oribatid mites (Acari) and its relevance to systematic relationships of Astigmata. International Journal of Acarology, 27: 281-292.

Sakata, T., S. Shimano and Y. Kuwahara (2003) Chemical ecology of oribatid mites III. Chemical composition of oil gland exudates from two oribatid mites, sp. and (Acari: Trhypochthoniidae). Experimental and Applied Acarology (in press)

Shimano, S. (2001) Secretions of oribatid mites. In: Biology of Ticks and Mites (ed., J. Aoki). University of Tokyo Press, Tokyo, pp. 130-153. (In Japanese)

Shimano, S., T. Sakata, Y. Mizutani, Y. Kuwahara and J. Aoki (2002) Geranial: The alarm pheromone in the nymphal stage of the oribatid mite, Nothrus palustris. Journal of Chemical Ecology, 28: 1831-1837.

Shimizu, N. and Y. Kuwahara (2001) 7-Hydroxyphthalide: A new natural salicylaldehyde analog from Oulenzia sp. (Astigmata: Winterschmidtiidae). Bioscience, Biotechnology, and Biochemistry, 65: 990-992.

Tomita, A., N. Shimizu, N. Mori, R. Nishida, H. Nakao and Y. Kuwahara (2003) Chemical ecology of astigmatid mites LXXI. Neryl formate (Z)-3,7-dimethyl-2,6-octadienyl formate as the alarm pheromone of Tyroborus lini Oudemans 1924, and its recovery after forced discharge. Journal of the Acarological Society of Japan, 12: 11-19.

\section{摘要}

コナダニ Oulenzia sp.の警報フェロモンとしてネラールの同定

清水 伸泰・野下 浩二・森 直樹・西田 律夫・桑原 保正（京大院農）

未同定種 Oulenzia sp. のヘキサン抽出物に警報フェロモン活性を認めた. ヘキサン抽出物 は, 2 種の未知化合物を含め, トリデカン, ネラール, ペンタデカン, ドデカン, 3-ヒドロ キシベンゼン -1,2-ジカルバルデヒド, ゲラニアール, $(Z)-7-$ ペンタデセン, 7-ヒドロキシフ タライドの 10 化合物で構成されていた. 抽出物をシリカゲルカラムで精製したところ, 活性 フラクションにはネラールとゲラニアールが含まれていた. ネラール（1-1000 ng で活性）は ゲラニアール（1000 ng でのみ活性）よりも強い活性を示すことから， ネラールを本種ダニ の警報フェロモンと同定した. 